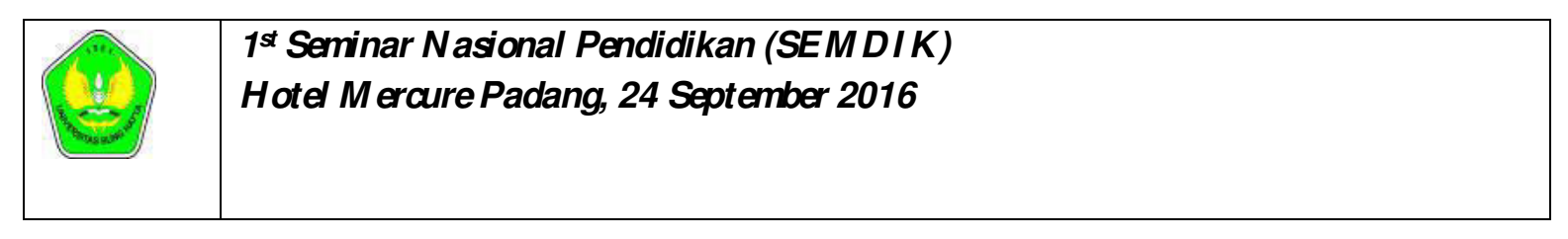

\title{
STRATEGIES FOR DEVELOPING PRE SERVICE TEACHERS' SCIENTIFIC SKILLS \\ Towards a Resourceful Teaching of Primary Science in Facing AEC
}

\author{
Erwinsyah Satria \\ Elementary School Teacher Education Program, Faculty of TeacherTraining \\ and Education, Bung Hatta University \\ erwinsyahsatria.rr@gmail.com
}

\begin{abstract}
The quality and performance of teachers are always considered as determining factors for the success of educational system of a nation. Pre service teachers in the primary education should be well equipped to meet the challenges of teaching primary science effectively in facing ASEAN Economic Community so that the students can use their developing scientific knowledge, skills, and attitudes to further develop their investigative skills and attitudes. It is therefore imperative to develop scientific skills among our pre service teachers for a resourceful teaching of primary school science. This paper discussed the strategies for developing pre service teachers' scientific skills in lesson preparation and after lesson delivery so as to create positive attitudinal outcomes and conditions necessary for inculcating scientific skills into the pupils. These will place the pre service teachers in a better and more resourceful position to teach science at the primary school level.
\end{abstract}

\section{Keywords: Strategies; Scientific Skills; a Resourceful Teaching of Primary Science}

\section{A. INTRODUCTION}

Responsding to the realization of Asian Economic Community (AEC) education institution in Indonesia are required to cope with problems education concerned with the development of the quality of human resources, system teaching, performance of teachers and expected to face the challenges age growing rapidly. One of a fairly significant impact of actual AEC was raise of profesional foreign workers, including the insides were educators or better known as teachers (Wangkey, 2014). This phenomenon will be new problems in Indonesia, especially in the sectors of elementary education, medium, and colleges. Until now, could not denied that the Indonesia government still struggling with the complexity of educational changes problems.

The quality and performance of teachers are always considered as determining factors for the success of educational changes. Since the 1980s, the decline in quality of teachers has become an issue of concern to the education sector (Education Department, 1990). The success of schools and colleges to fulfill the need to prepare students to meet intended societal changes depends on new patterns of teachers' training (Thomas, 2002). However, poor qualification and limited abilities together with low level of educational personnel, insufficiency in number and low level of professional morale are common in many lowincome countries (Amare, 1998). Such condition indeed will weaken the role that teachers could play in the provision of quality education in particular and societal development 
endeavour in general. Profesionalism teachers in Indonesia are still inadequate is one of the problems education word need to look for a solution, that they are able to compete withexertion master of foreign. AEC will demand for competition in the services sector that require profesionals reliable.

Primary education is pivotal to the development of any nation. Hence, primary school teachers are the nation builders in that they are the ones that lay the foundation of primary education upon which monumental super structure of secondary and tertiary education are solidly erected. If the foundation is faulty, then the whole system is faulty. It was on this note that the National Education Standard Board (BSNP, 2003) stressed that the rest of education system is built in primary education and it is the key to success or failure of the whole system of education. Arguments supporting the need for science education in elementary schools have been based on the desire to develop in students the knowledge, reasoning and problem solving skills required for a rapidly changing and technology based society (KTSP, 2006).

While research does indicate a closer accord between existing reform ideas and science education in some areas, there remain sources of concern for science educators (Weiss, 1994). For example, less than a third of elementary teachers felt they were well qualified to teach science (Weiss, 1994), many classroom teachers felt uncomfortable and unqualified when asked to teach science (Esler \& Esler, 1996; Abell \& Roth, 1991), and many experienced teachers, along with teachers who had recently completed their preservice education, expressed a lack of confidence in their ability to teach science (ASTEC, 1997). The important objectives for science education embodied in national statements such as National Policy on Education will not be achieved if elementary teachers continue to feel inadequately prepared, and lack the confidence, to teach science effectively in elementary schools.

Teachers as profesional worker should apply the principle of profesionalism who always held in high esteem and run in any process learning with an emphasis on the qualification important, competence, and certification, so that it is hoped that teachers able to face the changes that occured in various fields community life, especially for the education sector. Based on contemporary ideas about the teaching of science, it is suggested that the effectiveness of classroom science teaching may be investigated using an analytical framework that takes into account the beginning teacher's preparation and implementation of lessons and the classroom learning environment established by the teacher/pre service teacher.

Neale et. al (1990), Kruger and Summers (1993) and Taylor et. al (1994) developed criteria for judging the effectiveness of planning and teaching of science in elementary schools. The criteria they established were: (a) conceptual accuracy, (b) conceptual emphases, (c) extent of the use of appropriate representations such as analogies, examples or metaphors and any linkage of these to the students' interest and everyday experiences, (d) appropriate tasks or activities, (e) the use made of students' ideas, (f) science teaching strategies, (g) flexibility, or the teacher's ability to responsd to various situations and 
opportunities and, (h) appropriate differentiation and clarity of progression through the teaching sequence. In addition, teachers should establish classroom-learning environments that are sensitive to constructivist philosophies in order to cater effectively for students' learning. Teachers of primary schools are known to be responssible, respectable and recognizable due to their pioneering effort in the field of education. The most unfortunate thing is that little attention is paid to the development of human and material assets in the primary school sector (Aluko, 2007). Consequently, it becomes imperative to develop in the teacher the scientific skills needed for a resourceful teaching of primary science.

\section{B. DISCUSSION}

The Role and Characteristics of Primary School Teachers Primary school teachers teach and facilitate the learning of children ranging in age from 6 to 12 years in primary 1 to primary 6. In general, they identify children's individual and collective learning needs, plan and deliver instruction based on student learning needs and special needs, provide a stimulating learning environment in which each child can experience growth, and develop to his/her maximumpotential.

Elementary classes vary in size and often include students who represent a broad range of abilities, interests, needs and problems. A variety of instructional techniques are required to maintain student interest and maximize individual learning. In addition to preparing and presenting lessons, elementary teachers prepare and implement remedial programmes for students requiring extra help by preparing short-term and long-term learning objectives. Teachers meet with parents, meet with other professionals to discuss individual student needs and progress, organize and direct the work of parent volunteers, supervise extracurricular and after-school activities, and attend meetings, seminars and in- service training sessions. Teachers also develop and implement enrichment programmes for academically advanced students, and deal with children's crises such as forgotten lunches, minor scrapes, family emergencies, or not being picked up as scheduled. Most of these additional duties occur outside regular school hours and add considerable length to the working day. Most elementary teachers are responssible for a class of 14 to 40 children and teach most of the required subjects. Some teachers are specialists who teach related classes at different grade levels. Still others team-teach.

Elementary teachers who have specialized in Early Class Education are trained to work with children from primary 1 to primary 3 . These programmes focus on the development of positive self-concepts in young children, and include planning, organizing and providing a wide variety of experiences that foster understanding and use of language through practical experiments, stories, discussions, songs, art, games and other exploratory learning activities, listening experiences, and individual and group activities and projects. The following characteristics are required by the primary school teachers (Esler \& Esler:1996):

(i) A genuine interest in children and respect for their individuality,

(ii) The ability to sense children's individual needs,

(iii) The ability to be creative, imaginative, patient, energetic, organized and resourceful,

(iv) The ability to establish rapport and enjoy contact with the public, especially parents, 
(v) Strong leadership qualities and a good sense of humour,

(vi) A high level of dedication to work which often infringes on personal lifestyle choices,

(vii) A clear, pleasant speaking voice, and

(viii) Good mental, emotional and physical health.

(ix) Successful elementary school teachers enjoy finding different ways to solve questions and present information, and organizing and coordinating the work of others.

Rationale for Teaching Primary Sciencei In Indonesia

The justification for teaching primary science in Indonesia is entrenched in the National Policy on Education. The knowledge of science is essential in the training of technicians, medical doctors, engineers, architects, geologists, pilots, pharmacists, nurses, aeronautical engineers and information scientists. Science and technology are in separable. Technology is the application of scientific principles to solve human problems. Parts of human problems are communication, transportation, economic activities, and the host of other. The impact of science and technology has brought unquantifiable progress in the all spheres of human endeavour.

The scientific skills must be developed early in children before they get to the higher level in education. The pupils need good exposure to some basic scientific skills. These skills must be entrenched into their curriculum so that as they grow older, the curriculum will be getting spirally wider with emphasis on scientific discoveries.

Eshach (2006), outlines alternative rationales and a number of approaches to do a good science education by which he means one "that will nurture scientific thinking skills and inculcate in children the desire and passion to know and learn" (p. xii). He provides an excellent overview of his rationale for why science should be taught in early childhood. He offers six justifications for exposing young children to science as follows:

1. Children naturally enjoy observing and thinking about nature: 'A child's world is fresh and new and beautiful, full of wonder and excitement' (Carson, 1984, p.42). Because of their innate curiosity, children eagerly embrace all types of science activities. What makes children particularly ready for science is this intrinsic motivation, which refers to doing an activity for its inherent satisfaction rather than for some separable consequences. Some may say children just play during these science activities; however according to Vygotsky, play is the leading factor for the development of relationships between objects, meanings, and imaginations. This is one of the most important arguments for including science in pre- schools.

2. Development of attitudes toward science starts at the early stages of life. Exposing students to science in environments where they can enjoy science develops positive attitudes towards science. Early exposure to scientific phenomena leads to better understanding of the scientific concepts studied later in a formal way.

3. Since teaching science involves introducing the learner to the social language of school science (Scott, 1998), the use of scientifically informed language at an early age influences the eventual development of scientific concepts.

4. Children can understand scientific concepts and reason scientifically: Though there is no 
consensus on whether or not small children can think scientifically or whether they are mature enough to understand (abstract) scientific concepts, some research indicates that even younger children show the ability to think scientifically and they are able to think about even complex concepts (Metz, 1995).

5. Science is an efficient means for developing scientific thinking: It is essential to encourage students to develop scientific modes of explanations and modelling (Acher et al. 2007) and to develop the science process skills from the earliest school age. Objectives of Teaching Elementary Science

The goals of elementary science teaching in accordance with the National Education Standards Agency (BSNP) in KTSP (2006: 484) are to (1) obtain faith to the greatness of God Almighty based on the existence, beauty, and the natural order of creation, (2) develop knowledge and understanding of science conceptsthat are useful and applicable in everyday life, (3) develop curiosity, positive attitude and awareness of mutual influence among science, environment, technology and society. (4)develop process skills to investigate the nature surround them, solve problems and make decisions. (5) raisetheir awareness to participate in maintaining and preserving the natural environment. (6) raise their awareness to appreciate nature and its regularity as one of God's creation. (7) acquireknowledge, concepts and skills of science as a basis for continuing education to Junior High School (SMP / MTs).

Inculcating Scientific Skill in Lesson Preparation

To make the teaching of science interesting, eventful and resourceful, it is expected of every efficient science teachers to inculcate scientific skill in lesson preparation. How can this be done? It can be done by simply asking one self the following questions?

1. What do I wish to accomplish with this lesson?

2. Are the pupils ready for the lesson?

3. What do the pupils already know about the topic?

4. What are the instructional materials needed to be utilized in teaching a particular topic?

5. Are the instructional materials adequate, suitable and relevant?

6. Do the method and material suit the age group that would be recipient of that lesson?

7. How can I build on what the pupils have already known?

8. Which teaching method will best illustrate the main points of the lesson?

Positive answers to these pertinent questions will definitely reflect on how scientifically skillful such teacheris.

Scientific Lesson Delivery

The quality of lesson delivery can easily be judged by the method of teaching utilized by the teacher. Ideally, an effective and efficient teacher should use at least a combination of two methods in a single lesson. There are two major types of method, which are scientifically inclined. The first groups are traditional method, which are rarely used while the second 
groups are modern method. The traditional methods are demonstration, discussion and project approach.

However the following methods are recent and are more scientifically inclined. These are:

1. Guided discovery: This method implies that the teacher will provide carefully worded instruction that will help pupils solve problems after miscellaneous materials might have been given that can help them solve a given riddle.

2. Team teaching: In this method, an ad-hoc arrangement in which two or more teachers teach a topic is involved. The interest of the pupils is of paramount importance and not teacher's convenience.

3. Cooperative learning: This method involves division of pupils into mixed ability groups for the purpose of peer tutoring.

4. Process approach: This method involves using the skills that can make pupils to act like scientists. The skills include those of observation; recording; classification etc. the method is easily combined with any other method.

Skill-Based Teaching Activities

Pre service teachers should demonstrate skill-based teaching activities before the lesson delivery, during the lesson delivery and after the lesson delivery.

Skillful Discipline

Pre service/Trained teachers should be skillful in exercising self-discipline in all matters at all time. This will enable him to imbue self-discipline in the zestful heart of the pupils. The teachers are expected to create a friendly environment by being democratic enough. This will foster cooperation among the pupils.

Skillfulness in Taking Precautionary Steps

Science teachers are safety conscious. The teacher should be conscious of the any hazardous situation in the class or school environment and be prepared to take precautionary steps to prevent any accident. Sometimes, despite all safety precautions, accidents do occur. If accident occurs, science teachers should have the skills in giving first aid treatment before the pupils are eventually mobilized to a nearby hospital.

Skillfulness in Wholistic Evaluation

The teacher should be skillful in evaluating the total personality of each child. This will include manipulative and operative dexterity, understanding of the subject matter, laboratory skills and all aspect of pupil's affective domains.

Demonstration of Skills After Lesson Delivery

The science teacher should still sustain the interest of the student outside the regular classroom activities. He can do this by: (1). Giving home work, (2). Keeping anecdotal reports on each child.

\section{a. Homework}

Research has shown that homework is a follow-up of all the activities done in the school. Teacher should give homework to pupils on a regular basis. This will help to sustain the skills already taught in the school. 
b. Anecdotal Reports

Pupils' notebooks should be examined and corrected with signature and date on a regular basis. All the statutory reports on each pupil should be written as at when due and be recorded for future reference.

\section{c. Attitudinal Outcomes in Science}

Teachers often sacrifice attitudinal aspect of pupils on the altar of cognitive domain. This should not be. A balanced-learning in science must take into consideration the affective domain, psychomotor domain and then cognitive domain. Teacher can help pupils develop scientific attitudes, which are germane to scientific discovery. These attitudes are:

1. Objectivity: Scientists are always objectives at all time. Pupils should be trained to imbibe the spirit of supporting statements supported by evidential prove rather than sheepishly believing unsubstantiated opinion.

2. Inquisitiveness: Teacher should develop a curious mind in his/her pupils. He should teach them how to ask questions, how to find information through searching, reading and carrying out independent investigations.

3. Intellectual honesty: Science deals with absolute truth about a phenomenon. The absolute truth must be truthfully reported. Pupils must be taught on how to truthfully report their observations.

4. Maturity in decision-making: Scientists are not noted for rash decision. They are noted for accumulation of abundant evidence before taking decision. Teacher should develop the intellectual ability of their pupils in being mature in dispensing judgment. Teach them to accumulate enough facts and figure before drawing conclusion.

5. Critical-mindedness: Scientists are not gullible. Teachers should toughen the mind of their student in insisting for evidence before believing any assertion. Pupils should be trained on how to ask question such as, how do I believe what you are saying? Are you sure of what you are saying?

6. Open-mindedness: Teacher should also teach them not to be stubbornly glued to an opinion. They must recognizethat no "condition is permanent". Things do change. What is right today could be wrong tomorrow. Today's discoveries may nullify yesterday's ideas and innovation.

7. Reorganization of one's limitation: Nobody has the monopoly of knowledge. Teacher.

8. should develop the attitude of humanity in the pupils to recognize their own limitation and accept their mistake when convinced and corrected by colleagues or adults.

They should also be taught about the limitation of science, supremacy and sovereignty of God who may suspend all scientific principles to bring about a divine phenomenon.

Conditions Necessary for Scientific Skill Acquisition And Inculcation Into Our Pupils

1. Factual regurgitation should be de-emphasized. Education of pupils should rather be based on performance of skills

2. Materials need for experimentation must be handy and ready. Where actual materials are not available, teacher should improvise. 
3. At the on set of the teaching, teachers must know exactly what he wants to teach. He must have a clear understanding of the skill objectives.

4. Teachers must concentrate on a limited number of skills in any lesson.

5. Ample time must be created for practice. Pupils canonly be proficient and efficient when they are allowed to constant practices.

6. Lastly, planning and implementation of teaching must revolve around the set objectives.

\section{CONCLUSION}

Since science is the bedrock of technology, it should be developed early enough at the primary school level in order to inculcate scientific skills in our pupils' right from their childhood stage. Strategies for developing scientific skills in the teachers needed for a resourceful teaching of primary science have been presented. These skills will result in fostering acquisition of concepts and development of scientific attitudes among the pupils.

\section{REFERENCES}

Abell, S.K. \& Roth, M. (1991). Coping with constraints of teaching elementary science: A case study of a science enthusiast student teacher. Paper presented at the Annual Meeting of the National Association for Research in Science Teaching, Lake Geneva, WI.

Acher, A., Arca, M. and Sanmarti, N. (2007). Modeling as a teaching learning process for understanding materials: A case study in primary education. Science Education, 91, 398-418.

Aluko, K. O. (2007). Developing scientific skills needed for a resourceful teaching of primary science. A paper presented at a workshop organized for primary school teachers by Osun StateGovernment in conjunction with State Universal Basic Education Board (SUBEB), Osun State, Nigeria on 26th - 27th September.

Amare Asgedom (2004). Debates in Research Paradigms: Reflections in Qualitative Research in Higher Education. The Ethiopian Journal of Higher Education, Vol. I (II) Pp. 41-62.

Australian Science Technology and Engineering Council (ASTEC) (1997). Foundations for Australia's Future: Science and Technology in Primary Schools.Canberra: AGPS.

BSNP. 2003. UU Sisdiknas No. 20. Jakarta: Depdiknas.

Carson, R. (1984). The Sense of Wonder. New York: Harper \& Row Publications.

Education commission (1992). Education commission Report No.5: The Teaching profession.Hong Kong: Government Printer.

Depdiknas. 2006. Kurikulum Tingkat Satuan Pendidikan. Jakarta: Depdiknas.

Eshach, Haim (2006). Science Literacy in Primary Schools and Pre-schools.Springer, Dordrecht, The Netherlands. p. xii

Kruger, C. and Summers, M. (1993). The Teaching and Learning of Science Concepts in Primary Classrooms: Two Case Studies. Unpublished paper, Primary School 
Teachers and Science (PSTS) Project, Oxford University Department of Educational Studies.

Metz, K. (1995). Reassessment of Developmental Constraints on Children's Science Instruction. Review of Educational Research, 65 (2), 93-127.

Neale, D. C., Smith, D., and Johnson, V. G. (1990). Implementing Conceptual Change Teaching in the Primary School. The Elementary School Journal,91 (2), 109131.

Scott, P. H. (1998). Teacher Talk and Meaning Making in Science Classrooms: A Vygotskian Analysis and Review. Studies in Science Education,32, 45-80.

Taylor, P. C. S., Fraser, B. J. and White, L. R. (1994, April). CLES: An Instrument for Monitoring the Development of Constructivist Learning Environments. Paper presented at the Annual Meeting of the American Educational Research Association, New Orleans, LA.

Thomas, E. (2002). Teacher Education Dilemmas and Prospects: World Yearbook of Education 2002. London. KOGAN PAGE Ltd.

Wangkey, Humhprey. (2014). Peluang Indonesia dalam Masyarakat Ekonomi ASEAN 2015. Info Singkat Hubungan Internasional DPR RI: Kajian Singkat Isu-Isu Terkini, Vol. VI No. 10/II/P3DI (Mei 2014:8). 